\title{
Model of Physical Activity Based on Perceptual Motor for Kindergarten Learner: Study Analysis of Energy System and Neurology
}

\author{
Yudanto $^{1}$, Sugiharto ${ }^{2}$, Hari Amirullah Rachman ${ }^{3}$, Setya Rahayu $^{4}$ \\ ${ }^{1,3}$ Faculty of Sport Sciences, Universitas Negeri Yogyakarta, Indonesia \\ ${ }^{2,4}$ Graduate School, Universitas Negeri Semarang, Indonesia \\ ${ }^{1}$ Corresponding author: yudanto@uny.ac.id
}

\begin{abstract}
Perceptual motor activity involves brain and body to complete motion tasks together. Perceptual motor activity is associated with academic achievement. This research aims to produce a model of physical activity based on perceptual motor for kindergarten learners and to conduct the study on energy system and neurology. The research method used was by research and development of Borg and Gall. The subjects of small group trials used 10 Kindergarten learners and large group trial subjects used 54 Kindergarten learners. Data analysis technique applied Content Validity Ratio (CVR), CVI (Content Validity Index) and Alpha Cronbach. The results are CVR $=0.600-1,000, \mathrm{CVI}=$ above 0.800, and Alpha Cronbach $=$ above 0.800. The research result is the formation of model of physical activity based on perceptual motor, which includes 2 (two) games, they are animal-themed game and plant-themed game. The study analysis of energy system is that the physical activity model based on perceptual motor uses anaerobic and aerobic energy systems, whereas neurology analysis shows that the process of perceptual motor occurrence, including: input, organization, integration, output, response, and feedback.
\end{abstract}

Keywords: Perceptual Motor Activity, Energy System, Neurology

\section{Introduction}

Perceptual motor is the ability produced by the interaction with the environment that involves the process of observation and the process of moving. Perceptual motor is a term used to associate between cognitive function and motion skills of children. The concept of perception motor refers to the collection of information obtained from the environment to produce motor behavior. The motion generated by the perception process depends on the information processing system that exists within human being. Perceptual motor ability can affect other abilities in human life such as; cognitive function, academic ability, social and emotional development, and self-concept. Perceptual motor is formed by the components of motion, namely: (1) body awareness, (2) spatial awareness, (3) motion quality, (4) directional awareness, (5) temporal awareness, and (6) relationship with objects outside the body, (Rachman, et.al, 2010).

Early age is an ideal opportunity for children to learn to develop control of their muscles and movements. Children at this time still like simple forms of movement such as jumping, jumping, running, throwing and kicking, (Nurtajudin, 2015). Fundamental motor exercises at the beginning in preschool play an important role and describe the physical, social and cognitive development of children, (Giannakidou, 2014). Physical activity programmed during a certain period during preschool has an impact on children's cognitive skills, (Hosseini, et.al., 2011). Perceptual motor is related to academic achievement, children who have good perceptual motor also have good cognitive, (Morales, et.al, 2011). Perceptual abilities in terms of visual, auditory and kinesthetic in children aged 4-6 years have a relationship with academic achievement in terms of reading, spelling, and mathematics, (Dhingra, et.al, 2010). The results suggest that in the learning in the form of switched room activity and the ability to change the direction of the elements in the perceptual motor, as well as the ability to react to audio and video signals are required motor skills in social interaction and also to participate in sports, (Barnet, et.al, 2008). The optimal age for developing perceptual motor and basic skills is the age of 3-6 years old, (Johnstone, et.al., 2011). Perceptual motor have a correlation with movement skills, (Johan, 2012).

This article provides information related to the development of physical activity based on perceptual motor for Kindergarten learners and examines in energy system and neurology aspects. 


\section{Methods}

The research method used to develop physical activity based on perceptual motor used the research and development of Borg and Gall. The subjects of small group trials employed 10 Kindergarten learners and large group trial subjects employed 54 Kindergarten learners. Data analysis technique was by using Content Validity Ratio (CVR), CVI (Content Validity Index) and Alpha Cronbach. The theoretical study analysis is used to examine the energy system and neurology contained in the perceptual motor-based physical activity.

\section{Results and Discussion}

The research result is the formation of motor-based perceptual motor activity, which includes 2 (two) games, they are animalthemed game and plant-themed game. CVR test result shows the content validity of physical activity model based on perceptual motor is good or has high content validity, with CVR result in the range $0.600-1.000$ that is above 0.30 . While CVI test result has high degree of validity.

Table 1. Result of CVI Test of Physical Activity Model Based on Perceptual Motor

\begin{tabular}{clc}
\hline No & \multicolumn{1}{c}{ Name of Game } & CVI \\
\hline 1. & Animal-Themed Game & 0.924 \\
2. & Plant-Themed Game & 0.905 \\
\hline
\end{tabular}

The reliability test of physical activity model based on perceptual motor uses Alpha Cronbach. Result of reliability test is as follows.

Table 2. Result of Reliability Test of Physical Activity Model Based on Perceptual Motor

\begin{tabular}{|c|c|c|c|}
\hline No & $\begin{array}{l}\text { Name of } \\
\text { Game }\end{array}$ & $\begin{array}{c}\text { Coefficient } \\
\text { of } \\
\text { Correlation }\end{array}$ & Status \\
\hline 1. & $\begin{array}{l}\text { Animal- } \\
\text { Themed } \\
\text { Game }\end{array}$ & 0.951 & Reliable \\
\hline 2. & $\begin{array}{l}\text { Plant- } \\
\text { Themed } \\
\text { Game }\end{array}$ & 0.925 & Reliable \\
\hline
\end{tabular}

The scale of accomplishment of physical activity model based on perceptual motor consists of 4 (four) scales: scale 1 (very less acceptable/ less good), scale 2 (less acceptable/ less good), scale 3 (acceptable) and scale 4 (very acceptable / excellent). Average test result for the implementation of physical activity model based on perceptual motor in small scale test is 3.8 (accepted / good) and large scale test is 3.9 (acceptable/good).

\subsection{Analysis of Energy System of Physical Activity Based on Perceptual Motor of Animal- Themed Game and Plant- Themed Game}

Sport activities generally do not only purely use either aerobic or anaerobic system. What actually happens is a combination of aerobic and anaerobic systems, but the share of the two systems is different in every sport. For sports that require high intensity of physical activity with relatively short time, predominant energy system is anaerobic, whereas in sports that require low intensity physical activity and last for a relatively long time, the predominant energy system is aerobic. So, to determine whether the predominant energy system in a sport is essentially how much energy is provided and the length of time it takes for the performance of the sport; is not determined by the kind of movement itself.

\section{Anaerobic Energy System}

Anaerobic energy system can usually be known from time to time used in completing works. Anaerobic energy systems work in a short and relatively quick time as well as with its high intensity. This energy system is reenergizing without oxygen. Energy sources used are ATP-PC and Acid lactate systems, (Singh, 2015).

\section{Aerobic Energy System}

Aerobic energy system can usually be known from the time used in completing the work. This energy system can work continuously for a long time with low intensity. Aerobic energy system can reenergize back with oxygen. Aerobic exercise requires oxygen without causing oxygen charge, then these exercises can take place in a time long. Meanwhile, the effect of exercise is to increase body capacity to put the oxygen in and channel it into the cell systems to be 
combined with nutrients to produce energy, (Singh, 2015).

\subsection{Analysis of Neurology of Physical Activity Based on Perceptual Motor}

The process of motor perceptual begins with the acceptance of information from the environment to produce motion. The process of perceptual motor passes through several stages, namely: input, organization, integration, output, response, and feedback,
(Rachman, et.al., 2010). Input serves to receive various forms of stimulation both internal and external which then forward it in the form of nerve pattern to the brain. Organization, functions to collect and arrange all the stimuli generated by sensory devices to then be selected for use or otherwise stored back for the future. Integration works to match new information with information that has been stored in the previous process.

Table 3. Analysis of Energy System in Animal - Themed Game and Plant - Themed Game

\begin{tabular}{|c|c|c|c|c|}
\hline $\begin{array}{l}\text { Name of } \\
\text { Game }\end{array}$ & $\begin{array}{l}\text { Physical } \\
\text { Activity } \\
\end{array}$ & $\begin{array}{c}\text { Length } \\
\text { (Second) }\end{array}$ & Intensity & $\begin{array}{l}\text { Classification of } \\
\text { Energy System }\end{array}$ \\
\hline \multirow{4}{*}{$\begin{array}{l}\text { Animal- } \\
\text { Themed } \\
\text { Game }\end{array}$} & Frog Jumping & 10 & High & Anaerobic \\
\hline & Hopscotch with & 10 & High & Anaerobic \\
\hline & Right Leg & & & \\
\hline & $\begin{array}{l}\text { Hopscotch with } \\
\text { Left Leg }\end{array}$ & 10 & High & Anaerobic \\
\hline Plant- & Forward Tiptoe & 30 & Low & Aerobic \\
\hline Themed & Backward Tiptoe & 30 & Low & Aerobic \\
\hline \multirow[t]{4}{*}{ Game } & $\begin{array}{l}\text { Jumping and } \\
\text { Landing in Hoop }\end{array}$ & 10 & High & Anaerobic \\
\hline & Crawling & 30 & Low & Aerobic \\
\hline & $\begin{array}{l}\text { Right Sideway } \\
\text { Walking }\end{array}$ & 30 & Low & Aerobic \\
\hline & $\begin{array}{l}\text { Left Sideway } \\
\text { Walking }\end{array}$ & 30 & Low & Aerobic \\
\hline
\end{tabular}

Output serves to translate information that has been incorporated into new nervous energy pattern which then generates a response. Response is a visible activity in the form of motion. Feedback, is a place where visible responses providing information to the excitatory cycle part, which causes decrease in stimuli that have been modified to be delivered as new inputs. The workflow of this system can be seen in Figure 1.

The work of the system in Figure 1 can be exemplified by the activity of throwing the ball to a target. Input receives excitement in the form of target size, target distance, weight of the ball and others. The received input is then selected and combined with previously stored stimuli to then generate response in the form of throwing. If the target is not achieved, it will provide feedback in the form of new stimuli in the form of information that the throw is too low or too high or too weak. The new stimuli generated from this feedback are reprocessed by the system until the response seems to reach the expected goal. Thus it can be argued that feedback is the key to the concept of motor perceptual development, which ensures that the perception of motion learning goes simultaneously. 


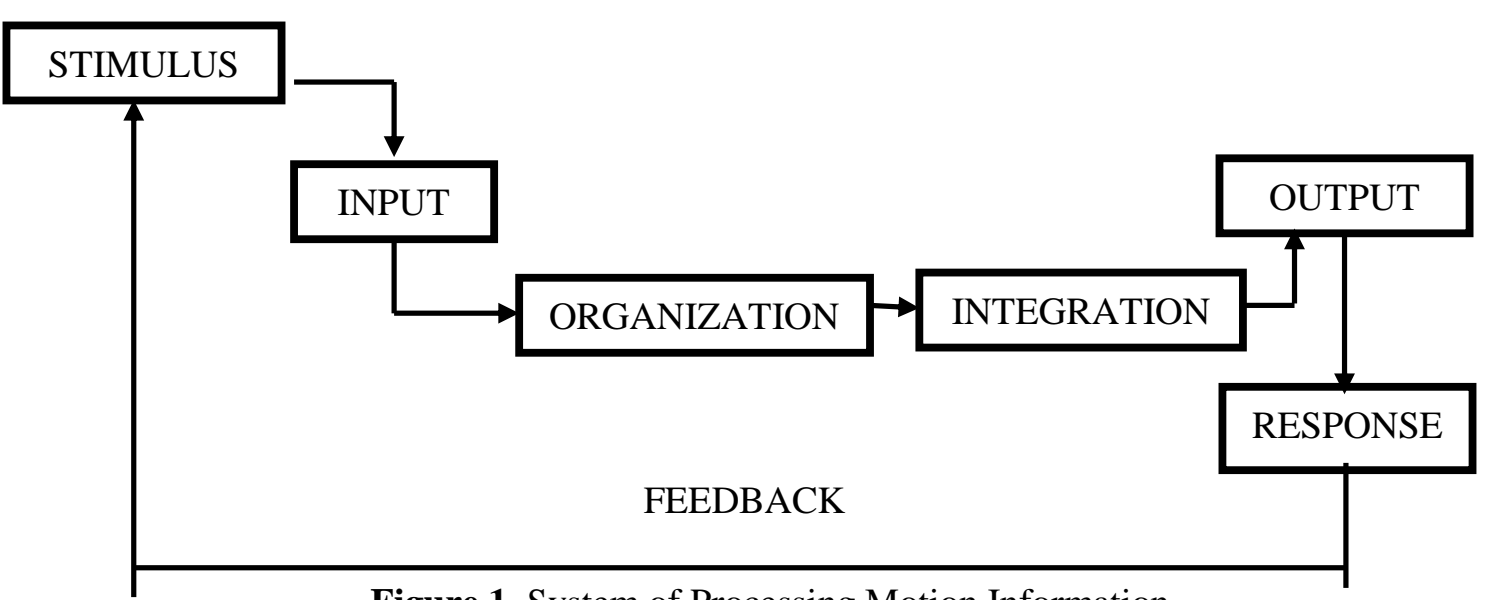

Figure 1. System of Processing Motion Information

Motion responds to feedback information to the correct perception, the chosen perception then raises the right response as well. This process continues until motion data and perceptual data are appropriate. As exemplified when throwing a ball, if at the first opportunity fails, then on the second occasion there are elements that are improved such as power or release angle. This is done continuously based on perceptions received from previous throws.

\section{Conclusion}

The result of this research is the formation of the model of physical activity based on perceptual motor, which includes 2 (two) games, they are animal-themed game and plant-themed game. The analysis of the energy system study is that the physical activity motor based on perceptual motor uses anaerobic and aerobic energy systems, whereas neurology analysis shows that the process of perceptual motor occurrence, including: input, organization, integration, output, response, and feedback.

\section{References}

Barnett, L.M., Morgan, P.J., Van B.E., \& Beard, R.J. (2008). Perceived Sports Competence Mediates the Relationship Between Childhood Motor Skill Proficiency and Adolescent Physical Activity and Fitness: A Longitudinal Assessment. International Journal of Behavioral Nutrition and Physical Activity, 5 (40): 1-12.

Dhingra, R., Manhas, S., \& Kohli, N. (2010). Relationship of Perceptual Abilities with Academic Performance of Children. Journal Soc. Sci., 23 (2): 143-147.

Giannakidou, D.M., Nastou, K., Karanatsiou, F., Paulidou, S., \& Antonis, K. 2014. A Review of the Relationship Between Physical Activity and Motor Proficiency in Children. European Psychomotricity Journal, 6 (1): 52-59.

Hosseini, S.S., Panahi, M., Naghilo, Z., \& Ramandi, L. D. (2011). The Effect of Exercise Training on Perceptual Motor Skills and Physicaal Fitness Factors in Preschool Children. Middle-East Journal of Scientific Research, 9 (6): 764-768.

Johan, S. (2012). The relation between basic movement skills and perceptual-motor skills in 5 to 7 years old children. European Psychomotricity Journal, 4 (1): 5765.

Johnstone, J. A. \& Ramon, M. 2011. Perceptual-Motor Activities for Children. USA: Human Kinetic.

Morales, J., Gonzales, L. M., Guerra, C. V., Virgili, C., \& Unnithan, V. (2011). Physical Activity, Perceptual Motor Performance, and Academic Learning in 9 to 16 Years Old School Children. International Journal of Sport Psychology, 42: 401-415.

Nurtajudin, Rahayu, T. \& Sulaiman. (2015). Pengaruh Latihan Koordinasi MataKaki-Tangan dan Tingkat Keseimbangan terhadap Motorik Kasar Anak Usia Dini. Journal of Physical Education and Sports, 4 (2): 154-158. 
Rachman, H.A. \& Muhamad, M. 2010. Membangun Kembali Jembatan antara Kreativitas dan Pendidikan Jasmani. Jurnal Motion, 1 (1):11-12.

Singh, M. (2015). Aerobic and Anaerobic Capacity between Rural and
Urban Football Male Players of Haryana - a Comparative Study. International Journal of Physical Education, Sports and Health, 2 (2): 03-05. 